\title{
Microbiological Quality of Industrial and Artisanal Pasta from Italian Market
}

Vittoria Ricci, Francesca Barone* and Letizia Petrella

Agenzia Regionale Protezione Ambiente Campania, Benevento, Italy

Correspondence to:

Francesca Barone

Agenzia Regionale Protezione Ambiente

Campania, Benevento, Italy

Tel: 00393284948010,00390824041713

E-mail: f.barone@arpacampania.it

Received: January 10, 2017

Accepted: March 16, 2017

Published: March 20, 2017

Citation: Ricci V, Barone F, Petrella L. 2017. Microbiological Quality of Industrial and Artisanal Pasta from Italian Market. J Food Chem Nanotechnol 3(2): 44-49.

Copyright: (C) 2017 Ricci et al. This is an Open Access article distributed under the terms of the Creative Commons Attribution 4.0 International License (CC-BY) (http://creativecommons. org/licenses/by/4.0/) which permits commercial use, including reproduction, adaptation, and distribution of the article provided the original author and source are credited.

Published by United Scientific Group

\section{Abstract}

The aim of this study was to evaluate the microbiological quality of fresh and dried pasta products, both industrial and handicraft. A total of 85 different samples (5 aliquots per sample) were collected from retail market. Parameters investigated were enumeration of total count of aerobic mesophilic bacteria at $30{ }^{\circ} \mathrm{C}$, coliform bacteria, $\beta$-glucuronidase-positive Escherichia coli, presumptive Bacillus cereus, coagulase-positive Staphylococci, Moulds, Listeria monocytogenes and the detection of Salmonella spp.

None of the samples tested contained Salmonella spp. and Listeria monocytogenes. Dried pasta showed generally an excellent hygienic-sanitary profile. Among fresh pasta the share of compliant samples, according to local regulation, was $78.8 \%$. Not packed fresh pasta was more contaminated and in particular if stuffed. Moreover, presumptive Bacillus cereus was present in almost $50 \%$ of the samples examined, confirming the importance of introducing the research of this microorganism in official control plans. A water activity greater than 0.92 , the processing steps and some ingredients used (in particular ricotta cheese) may increase bacterial growth by limiting the health and the shelf-life of this products. This study suggests that presumptive Bacillus cereus can be considered an indicator of process hygiene with different characteristics respect to coagulase-positive Staphylococci, because it appear more oriented to reveal problems with ingredients present in filling (almost cheese) from both industrial and artisanal production.

\section{Keywords}

Pasta, Bacillus cereus, Staphylococci coagulase positive, Microbiology

\section{Introduction}

Pasta is an ancient origin food, made of semolina or flour of different origin, with or without eggs, eventually stuffed with other ingredients. Pasta meals are efficient "delivery systems" for healthy foods. It is eaten with its plate partners, such as vegetables, fish, olive oil, cheese, tomato sauce, beans, poultry and meat. By pairing pasta with ingredients, the complete pasta meal is nutritious and satisfying. Pasta meals are central to the Mediterranean diet and current nutritionists consider pasta the food of the future $[1,2]$. Despite its great nutritional importance in the literature there are few studies aimed at evaluating its microbiological quality. Pasta can be either industrial or artisanal. Main steps of industrial production are: wheat grinding, mixing and kneading, extrusion, lamination (as an alternative to drawing), drying, cooling and packaging. The final moisture content shall not exceed $12.5 \%$, starting from a moisture content of approximately $35 \%$ [3]. Instead, artisanal production is usually hand-made without drying and 
packaging. The product can be classified depending on the moisture content in dried pasta and fresh pasta and according to the ingredients in pasta made from durum wheat semolina, special pasta and stuffed pasta. Italian dried pasta should have a moisture content of not more than $12.50 \%$, instead the fresh product should have a moisture content of not less than $24 \%$ and water activity (Aw) not less than 0.92 and not more than 0.97. There are several "paste stabilized" which have a moisture content not less than $20 \%$ and water activity not more than 0.92 [3]. Fresh pasta products are particularly vulnerable microbiological point of view [4] according with their water content, some stage in their processing and presence of some ingredients in the filling. Indeed their water activity is greater than 0.92 favoring bacterial growth and limiting the salubrity and the shelf life of the product. Moreover, their process, realizes favorable conditions for the development of certain pathogenic or potentially pathogenic microorganisms capable of producing heat-resistant toxins. Some of the ingredients in the filling, commonly used in fresh pasta production, can be an ideal substrate for the development of different microorganisms. The aim of this work is to evaluate the hygienic status of packed and unpacked pasta products (focusing in particular on the fresh ones) by enumeration of total count of aerobic mesophilic bacteria at $30{ }^{\circ} \mathrm{C}$, coliform bacteria, $\beta$-glucuronidase-positive Escherichia coli, presumptive Bacillus cereus, coagulase-positive Staphylococci, Moulds, Listeria monocytogenes and the detection of Salmonella spp.

\section{Materials and Methods}

Were analyzed 85 different samples (each consisting of 5 aliquots as disciplined by the Italian Ministry of Health with Circular August 3, 1985 n ${ }^{\circ} 32$ [4]), taken by Azienda Sanitaria Locale Benevento 1 (ASL BN1) staff in workshops (for unpacked pasta) in the province of Benevento and small and large retailers (for packed pasta).

The 85 samples analyzed were initially divided in two food categories:

- Dried pasta (19 samples)

- Fresh pasta (66 samples)

Distinguishing fresh pasta in:

- Stuffed fresh pasta (16 samples)

- Not stuffed fresh pasta (50 samples)

Data was subsequently re-evaluated by splitting fresh pasta samples in following four categories:

- Not stuffed packed fresh pasta (17 samples)

- Stuffed packed fresh pasta (8 samples)

- Not stuffed unpacked fresh pasta (33 samples)

- Stuffed unpacked fresh pasta (8 samples)

For each sample following parameters have been investigated:

Enumeration of microorganisms: total count of aerobic mesophilic bacteria at $30{ }^{\circ} \mathrm{C}$ (according to UNI EN ISO
4833-1:2013 [5]).

- Enumeration of coliform bacteria (according to ISO 4832:2006 [6]).

- Enumeration of $\beta$-glucuronidase-positive Escherichia coli (according to UNI ISO 16649-2:2010 [7]).

On 41 fresh pasta samples chosen taking into account the different ingredients (all stuffed samples, 6/17 not stuffed packed and 19/33 not stuffed unpacked) has been added investigation of:

- Enumeration of presumptive Bacillus cereus (according to UNI EN ISO 7932:2005 [8]).

- Enumeration of coagulase-positive Staphylococci (according to UNI EN ISO 6888-1:2004 [9]).

- Unpacked not stuffed fresh pasta samples (33) and unpacked stuffed fresh pasta samples (8) were tested for enumeration of moulds according to ISO 21527-1:2008-Parte 1 [10].

Furthermore all pasta samples, including 31 containing eggs between their ingredients, were investigated for detection of Salmonella spp. according to UNI EN ISO 6579:2008 [11] and enumeration of Listeria monocytogenes according to UNI EN ISO 11290-2:2005 [12].

The sample preparation was performed in accordance with the instructions contained in the UNI EN ISO 68871:2000 [13] and UNI EN ISO 6887-4:2012 [14]. Precisely for the determination of total count of aerobic mesophilic bacteria at $30{ }^{\circ} \mathrm{C}$, coliform bacteria, $\beta$-glucuronidase-positive Escherichia coli, presumptive Bacillus cereus, coagulase-positive Staphylococci and Listeria monocytogenes were added to $10 \mathrm{~g}$ of sample $90 \mathrm{ml}$ of Buffed Peptone Water (BPW), while for the detection of Salmonella spp. in $25 \mathrm{~g}$ of sample were added to 225 $\mathrm{ml} \mathrm{BPW}$. For each test run was performed a negative control and for each sample appropriate dilutions were performed.

All the methods used are validated and accredited by the Italian certification organization ACCREDIA.

Validation of all methods involved the use of positive samples (of course contaminated or artificially contaminated with a known concentration strains ATCC/NCTC) and thus itself serves as a positive control. In addition to the detection of Salmonella spp. in addition to validation, they were performed quarterly internal controls with target strains and no target as required by UNI EN ISO 6579: 2008 [11].

All culture media used were previously controlled in accordance with the UNI EN ISO 11133:2014 [15]. For each of the following parameters were evaluated: productivity, selectivity, specificity.

The results are expressed as "units forming colony" (UFC) in a specific mass ( $g$ ) of the sample, as required by ISO 7218:2013 [16], except for the parameter Salmonella spp. whose result is expressed as presence/absence. Analysis were performed in duplicate on each aliquot in order to evaluate data dispersion and/or linearity with the calculation of $\mathrm{Kp}$ and $\mathrm{G}^{2}$. Measurement uncertainty was calculated (according to ISO/TS 19036:2006 [17]) only for those samples having one or more parameters higher limit guide value, as reported 
by Italian Ministry of Public Health in Circular no. 32, 3 August 1985 [4] or in Technical Protocol by ARPA Piemonte "Microbiological criteria for foodstuffs that are not subject to specific legislation" [18] or ISTISAN Reports 89/9 [19] or Commission Regulation (EC) No 1441/2007 of 5 December 2007 [20] amending Commission Regulation (EC) No 2073/2005 [21]. Results were compared with the guideline value: if the lower limit was higher than the value used as a reference sample was considered non-compliant and is correlated to the failure in observing hygienic rules during production, or to the incorrect application of the same and or to using of poor health quality raw materials (ISTISAN Reports 89/9 [19]).

Furthermore, after calculating the mean for the five aliquots of every sample with Excel program, was performed a descriptive statistics analysis for each group of samples, using STATISTICA software (ver. 7.0 2004 Stat Soft), and an inferential statistics analysis (Mann-Whitney U test) in order to verify if the means of microbiological parameters in question were significantly different [22]. STATISTICA software, for small samples in computations for the MannWhitney $U$ test applies a continuity correction, instead, for small to moderate sized samples, it computes an exact probability associated with the respective $U$ statistic. This probability is based on the enumeration of all possible values of $U$ (unadjusted for ties), given the number of observations in the two samples. Specifically, for small to moderate sized samples, software reports the value $2^{*} \mathrm{p}$, where $\mathrm{p}$ is 1 minus the cumulative (one-sided) probability of the respective $U$ statistic. The assumption of no ties in the data (ranks) leads just to a small underestimation of the statistical significance of the respective effects. For the comparison with the normal distribution was used the statistical variable standard normal $\mathrm{Z}([-1,64 ; 1,64])$, taking 0.05 as $\mathrm{P}$-value.

\section{Results}

All 85 samples examined showed values below level of detection relatively to Salmonella spp. detection and enumeration of Listeria monocytogenes.

The dry pasta samples showed for total count of aerobic mesophilic bacteria at $30^{\circ} \mathrm{C}$ mean value $15 \mathrm{UFC} / \mathrm{g}$ ( 13 samples with values below level of detection) while for coliform bacteria and $\beta$-glucuronidase-positive Escherichia coli absence.

The fresh pasta samples showed for total count of aerobic mesophilic bacteria at $30{ }^{\circ} \mathrm{C}$ mean values $3.4 \times 10^{6}$ and $3.5 \mathrm{x}$ $10^{5}$ (respectively for fresh stuffed and not stuffed pasta). Also comparing the values of the total count of aerobic mesophilic bacteria at $30{ }^{\circ} \mathrm{C}$ with other parameters values, it emerged that the former are extremely higher than the second and affected by a high standard deviation (Figure 1 ).

The considerable variability obtained from this analysis has prompted us to re-evaluate the data held by further dividing fresh pasta samples in packed and unpacked though distribution of samples between these categories is not homogeneous. This because ASL staff, who performed the sampling, focused controls on unpacked pasta as presumably deemed subject to a greater hygienic risk.

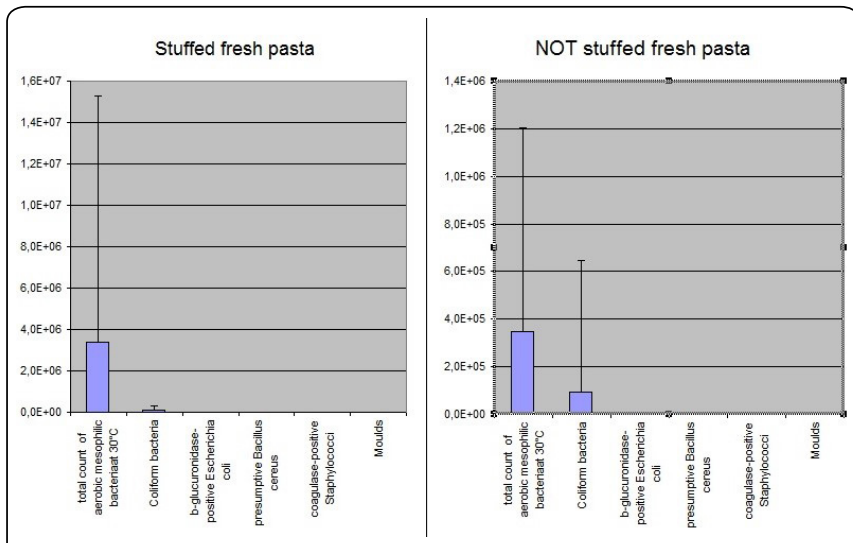

Figure 1: Mean values and standard deviation in stuffed and not stuffed fresh pasta for quantitative methods.

Examining samples of not stuffed packed fresh pasta was highlighted the presence of microorganisms, by total count of aerobic mesophilic bacteria at $30{ }^{\circ} \mathrm{C}$, in two-thirds of the samples. Remaining third samples showed values below level of detection.

Among the samples of stuffed packed fresh pasta, total count of aerobic mesophilic bacteria at $30{ }^{\circ} \mathrm{C}$, showed the presence of microorganisms in all samples tested except in a sample of cappelletti with mortadella and parmesan. Presumptive Bacillus cereus was present over detection level only in fresh stuffed pasta (4 samples). Presence of Bacillus cereus was highlighted in just one sample of packed fresh pasta (spinach and ricotta ravioli). Coliform bacteria were instead detected only in a sample of cavatelli, which also presented a total count of aerobic mesophilic bacteria at $30{ }^{\circ} \mathrm{C}$ higher than the reference value $(1,600,000 \mathrm{UFC} / \mathrm{g})$. In this Cavatelli sample there was no presence of $\beta$-glucuronidase-positive Escherichia coli and of presumptive Bacillus cereus. Coagulasepositive Staphylococci was below limit of detection in all samples.

Among samples belonging to the category of not stuffed unpacked fresh pasta was highlighted the presence of microorganisms (total count of aerobic mesophilic bacteria at $30{ }^{\circ} \mathrm{C}$ ) in $94 \%$ of samples tested. Coliform bacteria were detected in $79 \%$ of samples. $\beta$-glucuronidase-positive Escherichia coli and coagulase-positive Staphylococci were detected only in a sample, while presumptive Bacillus cereus was absent in all the samples examined. Furthermore moulds were detected in 12 samples (36.4\%).

Stuffed unpacked fresh pasta was the most contaminated group. In fact, total count of aerobic mesophilic bacteria at $30{ }^{\circ} \mathrm{C}$ highlighted the presence of microorganisms in all samples; three of them exceeded guideline values as reported by Circular No. 32/1985 [4]. Coliform bacteria, $\beta$-glucuronidasepositive Escherichia coli and coagulase positive Staphylococci were present mostly in this category. Coliform bacteria were present in all samples analyzed with parameter values exceed the limits imposed by the aforementioned Circular [4], except for two samples. $\beta$-glucuronidase-positive Escherichia coli was detected in all samples except in a sample of spinach and ricotta 
ravioli. Presumptive Bacillus cereus presence was found in 38\% of unpacked stuffed fresh pasta samples, with an extremely high concentration in a sample of eggplant and mozzarella ravioli (5700 UFC/g). Coagulase-positive Staphylococci was present just in one sample (ravioli) with a value that exceed the limit imposed by the Circular No. 32/1985 [4] (2400 UFC/g). Instead Moulds resulted below limit of detection for all samples. In Table 1 are reported mean and standard deviation of each group examined. count of aerobic mesophilic bacteria at $30{ }^{\circ} \mathrm{C}$ values.

\section{Discussion and Conclusions}

All product examined showed an excellent hygienicsanitary profile regarding absence of pathogenic microorganism (Salmonella spp. and Listeria monocytogenes).

Presumptive Bacillus cereus was over level of detection only in stuffed pasta, mostly if not packed. Coagulase-positive

\begin{tabular}{|c|c|c|c|c|c|}
\hline & \multicolumn{3}{|l|}{ Packed pasta } & \multirow{2}{*}{\multicolumn{2}{|c|}{$\begin{array}{l}\text { Unpacked pasta } \\
\text { Fresh pasta }\end{array}$}} \\
\hline & \multirow{2}{*}{$\begin{array}{l}\text { Dried pasta } \\
\text { Industrial (19 samples) }\end{array}$} & \multicolumn{2}{|l|}{ Fresh pasta } & & \\
\hline & & Not stuffed (17 samples) & Stuffed (8 samples) & Not stuffed (33 samples) & Stuffed (8 samples) \\
\hline $\begin{array}{l}\text { Total count of aerobic } \\
\text { mesophilic bacteria at } 30^{\circ} \mathrm{C}\end{array}$ & $0.52 \pm 0.79$ & $2.38 \pm 2.19$ & $4.26 \pm 1.92$ & $4.27 \pm 1.63$ & $5.49 \pm 1.45$ \\
\hline Coliform bacteria & $0.00 \pm 0.00$ & $0.20 \pm 0.82$ & $0.00 \pm 0.00$ & $2.66 \pm 1.75$ & $4.36 \pm 1.14$ \\
\hline $\begin{array}{l}\beta \text {-glucuronidase-positive } \\
\text { Escherichia coli }\end{array}$ & $0.00 \pm 0.00$ & $0.00 \pm 0.00$ & $0.00 \pm 0.00$ & $0.09 \pm 0.53$ & $1.67 \pm 1.12$ \\
\hline Presumptive Bacillus cereus & 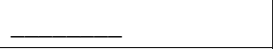 & $0.00 \pm 0.00^{* *}(6$ samples $)$ & $0.26 \pm 0.74$ & $0.00 \pm 0.00^{* *}$ (19 samples) & $0.88 \pm 1.42$ \\
\hline Coagulase-positive Staphylococci & $\ldots$ & $0.00 \pm 0.00^{* *}(6$ samples $)$ & $0.00 \pm 0.00$ & $0.19 \pm 0.73^{* *}(19$ samples $)$ & $0.42 \pm 1.19$ \\
\hline Moulds & 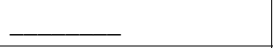 & - & - & $0.82 \pm 0.93$ & $0.00 \pm 0.00$ \\
\hline Salmonella spp. & Not detected & Not detected & Not detected & Not detected & Not detected \\
\hline Listeria monocytogenes & $0.00 \pm 0.00$ & $0.00 \pm 0.00$ & $0.00 \pm 0.00$ & $0.00 \pm 0.00$ & $0.00 \pm 0.00$ \\
\hline
\end{tabular}

Comparing data obtained and reference values considered (Circular No. 32 of 1985 [4] or Technical Protocol ARPA Piemonte [18] or ISTISAN Reports 89/9 [19] or Commission Regulation (EC) No 1441/2007 of 5 December 2007 [20]), was calculated measurement uncertainty only for samples with one or more parameters higher than its reference threshold. If the minimum value of the estimated range was higher than the reference value considered a judgment of non-compliance was attributed to the sample. Eighteen samples were found to be "non-compliant" according to enumeration of total count of aerobic mesophilic bacteria at $30{ }^{\circ} \mathrm{C}$, coliform bacteria, $\beta$-glucuronidase-positive Escherichia coli, presumptive Bacillus cereus, coagulase-positive Staphylococci. Finally, for each food category considered, the percentage of non-compliant samples was calculated. The largest percentage of non-compliant samples and thus more contaminated samples is always located in unpacked category, whether stuffed that not stuffed, as shown in Figure 2.

Using the Mann-Whitney $U$ test has been verified if the mean values of the microbiological parameters of the packed and unpacked groups were significantly different. Inferential statistics analysis results (Table 2) confirmed that the null hypothesis was rejected, so packed pasta group and unpacked pasta group resulted significantly different relatively to total

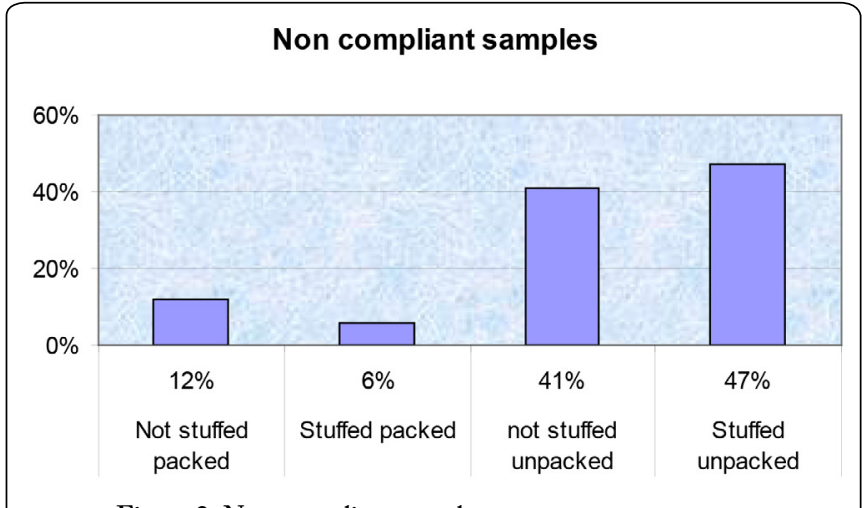

Figure 2: Non-compliant samples percentage per category.

Staphylococci was instead prevalent in not packed category, especially if stuffed. B-glucuronidase-positive Escherichia coli was mostly highlighted over level of detection in stuffed unpacked pasta (except in a case of not stuffed unpacked pasta). Total count of aerobic mesophilic bacteria at $30{ }^{\circ} \mathrm{C}$ showed the presence of microorganisms over level of detection in all types of pasta with greater values in the stuffed unpacked group, confirming that it is a good indicator of hygienic quality. Coliform bacteria are present over level of detection in unpacked samples (stuffed and not stuffed) and mostly below

Table 2: Inferential statistics analysis of Aerobic Plate Counts data. Mann-Whitney U Test applied to unpacked versus packed pasta group.

\begin{tabular}{|c|c|c|c|c|c|c|c|c|c|c|}
\hline \multirow[t]{2}{*}{ Variable } & \multicolumn{10}{|c|}{ Mann-Whitney U Test (Aerobic Plate Count APCs) by variable “Packed Pasta” Marked Tests are Significant at $P<, 05000$} \\
\hline & Rank Sum Packed & Rank Sum Unpacked & $\mathrm{U}$ & Z & p-level & $Z$ adjusted & p-level & $\begin{array}{l}\text { Valid N } \\
\text { Group } 1\end{array}$ & $\begin{array}{l}\text { Valid N } \\
\text { Group } 2\end{array}$ & $\begin{array}{l}2 * 1 \text { sided } \\
\text { exact } \mathrm{p}\end{array}$ \\
\hline Unpacked pasta & 190,0000 & 41,00000 & 0,00 & $-2,27636$ & 0,022825 & $-2,29280$ & 0,021860 & 19 & 2 & 0,009524 \\
\hline
\end{tabular}


level of detection in samples of packed pasta (except one case of positivity in a sample of not stuffed packed pasta). Moulds showed values over level of detection only in unpacked fresh pasta not stuffed.

The results of the Mann-Whitney $U$ test, applied to total count of aerobic mesophilic bacteria at $30{ }^{\circ} \mathrm{C}$ (the only parameters with values over level of detection in all categories evaluated), confirmed a greater contamination of the unpacked pasta than the packed one and the existence of a statistically significant difference, among this two group of pasta products. This results showed that packaging is the most significant discrimination in contamination of pasta products, more than being stuffed or not. In fact, $82 \%$ of non-compliant samples were unpacked pasta, with only $44 \%$ of this samples stuffed. Our data are similar to those reported from other work in literature for this type of samples [23].

Our results confirmed that coagulase-positive Staphylococci is a good indicator of process hygiene, for artisanal production of unpacked pasta [24]. Also highlighted was the presence over level of detection of presumptive Bacillus cereus, in almost fifty percent of 41 products tested (it was tested especially in stuffed products), confirming the importance of introducing monitoring of this organism in control plans [25]. It should also be underlined that among samples where presumptive Bacillus cereus was detected, $67 \%$ contains ricotta cheese as an ingredient of the filling, according to studies that reported presumptive Bacillus cereus presence in samples of cheese, founded non-confident with hygiene standards and HACCP rules $[26,27]$. This study suggests that presumptive Bacillus cereus can be considered an indicator of process hygiene with different characteristics respect to coagulasepositive Staphylococci, because it appear more oriented to reveal problems with ingredients present in filling (almost cheese) from both industrial and artisanal production.

Therefore, our data confirms the necessity of controlling during manufacturing, especially if handcraft, the critical control points, [28], starting from the selection of raw materials (especially regarding ingredients for the filling and in particular ricotta cheese). It will be so possible improving the shelf-life and wholesomeness of pasta. Furthermore this study suggests the importance of introducing in food laws, as control parameters for process hygiene, of $\beta$-glucuronidasepositive Escherichia coli counts, and presumptive Bacillus cereus.

In the present work we have evaluated moulds presence in artisanal local production and our data showed that it appear over level of detection in not stuffed unpacked fresh pasta, instead it was not present in stuffed samples. This probably happen because usually the stuffed production is immediately consumed, instead the not stuffed one is stored longer in the production workshop.

Overall, dried pasta, as described in literature [29], showed a better microbiological profile respect to the fresh one. Nonetheless, quality of artisanal production, was excellent, with absence of pathogens Salmonella spp. and Listeria monocytogenes and an extremely rare presence of $\beta$-glucuronidase-positive Escherichia coli (except in stuffed not packed fresh pasta category), indicator of fecal contamination.
In fact, the share of compliant samples resulted 78.8\%. Packed fresh pasta showed a better hygienic sanitary profile than unpacked one, especially if stuffed. Stuffed artisanal samples resulted to be susceptible to an higher microbiological risk, as result, in particular, of some ingredients used (in particular ricotta cheese) that may increase bacterial growth by limiting the health and the shelf-life of this products.

\section{References}

1. Linee guida per una sana e corretta alimentazione italiana. Istituto Nazionale di Ricerca per gli Alimenti e la Nutrizione. Revisione 2003.

2. Kris-Etherton P, Eckel RH, Howard BV, St Jeor S, Bazzarre TL. 2001. AHA science advisory: lyon diet heart study. Benefits of a Mediterranean-style, national cholesterol education program/ American heart association step I dietary pattern on cardiovascular disease. Circulation 103(13): 1823-1825. https://doi.org/10.1161/01. CIR.103.13.1823

3. G.U. n. 117 del 22/05/2001 DPR del 9 febbraio 2001, n.187.

4. Circular of the Italian Ministry of Health August 3, 1985, n 32 .

5. UNI EN ISO 4833:2013. Microbiology of food and animal feeding stuffs. Horizontal method for the enumeration of microorganisms. Colony-count at $30^{\circ} \mathrm{C}$ by the surface plating technique. Ente Nazionale Italiano di Unificazione, Milano, Italia.

6. ISO 4832:2006. Microbiology of food and animal feeding stuffs. Horizontal method for the enumeration of coliforms. Colony-count technique. International Organization for Standardization, Geneva, Switzerland.

7. UNI ISO 16649-2:2010. Horizontal method for the enumeration of betaglucuronidase-positive Escherichia coli. Part 2: Colony-count technique at $44{ }^{\circ} \mathrm{C}$ using 5-bromo-4-chloro-3-indolyl beta-D-glucuronide. Ente Nazionale Italiano di Unificazione, Milano, Italia.

8. UNI EN ISO 7932:2005. Microbiology of food and animal feeding stuffs. Horizontal method for the enumeration of presumptive Bacillus cereus - Colony-count technique at $30{ }^{\circ} \mathrm{C}$. Ente Nazionale Italiano di Unificazione, Milano, Italia.

9. UNI EN ISO 6888-1:2004. Horizontal method for the enumeration of coagulase-positive staphylococci (Staphylococcus aureus and other species). Technique using Baird-Parker agar medium. Ente Nazionale Italiano di Unificazione, Milano, Italia.

10. ISO 21527:2008. Microbiology of food and animal feeding stuffs. Horizontal method for the enumeration of yeasts and moulds - Part 1 Colony count technique in products with water activity greater than 0,95. International Organization for Standardization, Geneva, Switzerland.

11. UNI EN ISO 6579:2008. Microbiology of food and animal feeding stuffs. Horizontal method for the detection of Salmonella spp. Ente Nazionale Italiano di Unificazione, Milano, Italia.

12. UNI EN ISO 11290-2:2005. Microbiology of food and animal feeding stuffs. Horizontal method for the detection and enumeration of Listeria monocytogenes. Part 2: Enumeration method. Ente Nazionale Italiano di Unificazione, Milano, Italia.

13. UNI EN ISO 6887-1:2000. Preparazione dei campioni di prova, sospensione iniziale e diluizioni decimali per l'analisi microbiologica. Ente Nazionale Italiano di Unificazione, Milano, Italia.

14. UNI EN ISO 6887-4:2012. Preparazione dei campioni di prova, sospensione iniziale e diluizioni decimali per l'analisi microbiologica. Parte 4. Ente Nazionale Italiano di Unificazione, Milano, Italia.

15. UNI EN ISO 11133:2014. Preparazione, produzione, immagazzinamento e prove di prestazione dei terreni colturali. Ente Nazionale Italiano di Unificazione, Milano, Italia.

16. UNI EN ISO 7218:2013. Microbiology of food and animal feeding stuffs - General requirements and guidance for microbiological examinations. Ente Nazionale Italiano di Unificazione, Milano, Italia. 
17. ISO/TS 19036:2006. Microbiology of food and animal feeding stuffs - Guidelines for the estimation of measurement uncertainty for quantitative determinations. International Organization for Standardization, Geneva, Switzerland.

18. ARPA Piemonte-Technical Protocol "Microbiological criteria for foodstuffs that are not subject to specific legislation"; Accordo Direzione Sanità Pubblica Regione Piemonte e Agenzia Regionale per la Protezione Ambientale del Piemonte.Regolamentazione dell'attività inerente il controllo di alimenti, acque, cosmetici ed altro. [Regulation in matter of food, water, cosmetics and others controls]. 31/3/2006;

19. Aureli P, Papasso A, Fenicia L, Ferrini AM, Gianfranceschi M. 1989. ISTISAN Reports"Metodiche analitiche per il controllo microbiologico delle paste alimentari - ISTISAN 89/9-ISSN-0391-1675.

20. Commission Regulation (EC) No 1441/2007 of 5 December 2007 amending Regulation (EC) No 2073/2005 on microbiological criteria for foodstuffs.

21. Commission Regulation (EC) No 2073/2005 of 15 November 2005 on microbiological criteria for foodstuffs. Official Journal of the European Union L338/1, 22/12/2005.

22. Chiorri C. 2010. Fondamenti di psicometria. Milano: McGraw-Hill. (Italian: Handbook of introductory psychometrics.

23. Trovatelli LD, Shiesser A, Massa S, Cesaroni D, Poda G. 1988. Microbiological quality of fresh pasta dumplings sold in Bologna and the surrounding district. Int J Food Microbiol 7(1): 19-24. https://doi. org/10.1016/0168-1605(88)90068-2

24. Matéjovská V, Tichá J, Cernovský J. 1972. Findings of staphylococci in pasta products. J Hyg Epidemiol Microbiol Immunol 16(2): 148-151.

25. Rajkovic A, Kljajic M, Smigic N, Devileghere F, Uyttendaele M. 2013. Toxin producing Bacillus cereus persist in ready-to-reheat spaghetti Bolognese mainly in vegetative state. Int J Food Microbiol 167(2): 236243. https://doi.org/10.1016/j.ijfoodmicro.2013.09.001

26. Panico MG, Caporale V, Agozzino E. 2006. Investigating on a foodborne outbreak: analysis of the critical points. Ann Ig 18(3): 191-197.

27. De Santis EP, Foddai A, Virdis S, Marrongiu P, Pilo AL, et al. 2008. Toxin gene pattern in Bacillus cereus group strains isolated from sheep ricotta cheese. Vet Res Commun 32(Suppl 1): S323-S326. https://doi. org/10.1007/s11259-008-9139-6

28. Delbrassinne L, Andjeikovic M, Raijkovic A, Bottledoom N, Mahillon $\mathrm{J}$, et al. 2011. Follow-up of the Bacillus cereus emetic toxin production in penne pasta under household conditions using liquid chromatography coupled with mass spectrometry. Food Microbiol 28(5): 1105-1109. https://doi.org/10.1016/j.fm.2011.02.014

29. Akineden Ö, Murata KJ, Gross M, Usleber E. 2015. Microbiological quality of raw dried pasta from the German market, with special emphasis on cronobacter species. J Food Sci 80(12): M2860-M2867. https://doi.org/10.1111/1750-3841.13117 